\title{
Peningkatan Prestasi Belajar Peserta Didik Melalui Pendekatan Saintifik Model Pembelajaran Window Shopping (Kunjungan Galeri) Pada Materi Sistem Pencernaan Manusia Kelas VIII.8 SMPN I Praya Tahun Pelajaran 2019 - 2020
}

\author{
Muhamad Zaenal Mustopa \\ Guru Mata Pelajaran IPA SMPN 1 Praya Kabupaten Lombok Tengah
}

\begin{abstract}
Abstrak. Peningkatan Prestasi Belajar Peserta Didik Melalui Pendekatan Saintifik Model Pembelajaran Window Shopping (Kunjungan Galeri) Pada Materi Sistem Pencernaan Manusia Kelas VIII.8 SMP Negeri I Praya Tahun Pelajaran 2019-2020. Salah satu faktor yang mempengaruhi prestasi belajar peserta didik adalah penerapan model pembelajaran yang sesuai dengan materi yang diajarkan sehingga hasil belajar yang diperoleh sesuai dengan yang diharapkan Penelitian ini bertujuan untuk mengetahui peningkatan prestasi belajar peserta didik melalui pendekatan saintifik model pembelajaran Window Shopping (Kunjungan Galeri) Pada Materi Sistem Pencernaan Manusia. Penelitian ini adalah penelitian Tindakan Kelas (PTK), menggunakan tes hasil belajar yang digunakan untuk mengetahui peningkatan prestasi belajar peserta didik. Penelitian dilaksanakan di kelas VIII.8 pada semester I SMP Negeri I Praya pada tahun pelajaran 2019-2020. Peserta didik berjumlah 32 orang terdiri atas 16 putri dan 16 putra. Hasil penelitian adalah prestasi belajar peserta didik mengalami peningkatan sebesar $18 \%$ dari siklus I dan II. Berdasarkan hasil peneitian direkomendasikan agar guru mata pelajaran dapat menerapkan model pembelajaran window shopping (kunjungan galeri) dalam proses pembelajaran untuk meningkatkan prestasi belajar peserta didik.
\end{abstract}

Kata Kunci : Pendekatan Saintifik,Model Window Shopping, Prestasi Belajar

\section{PENDAHULUAN}

Berdasarkan

Peraturan Menteri Pendidikan Nasional RI nomor 22 tahun 2006 tentang standar isi satuan pendidikan dasar menengah, menjelaskan bahwa Ilmu Pengetahuan Alam merupakan salah satu bidang study yang dipelajari pada pendidikan di sekolah. IPA bukan hanya penguasaan kumpulan pengetahuan berupa fakta-fakta, konsep atau prinsip-prinsip saja tetapi merupakan suatu proses penemuan. Dalam pelaksanaannya IPA harus dirancang dengan kebutuhan, karakter dan kemampuan peserta didik. Tidak bisa hanya dilakukan dengan sekedar transfer ilmu (transfer knowledge) dari guru ke peserta didik. Tetapi harus mengarahkan peserta didik untuk berfikir kritis dan dapat menyelesaikan masalahnya sendiri (Problem Solving) yang disebut dengan pembelajaran Higher Order Thinking Skill (HOTS).

Pemerintah berupaya untuk merubah paradigma lama yaitu pembelajaran berpusat pada guru (Teacher Oriented) menjadi pembelajaran berpusat pada peserta didik (Student Oriented) dengan menerapkan kurikulum 2013. Perubahan orientasi tersebut mensyaratkan peran guru sebagai fasilitator dalam kegiatan pembelajaran, bukan sebagai tokoh utama. Guru diharapkan dapat memberikan kemudahan dan kesempatan bagi peserta didik untuk berperan aktif sepanjang kegiatan pembelajaran. Peran aktif peserta didik tersebut dapat terwujud dengan menerapkan metode pembelajaran kooperatif.

Pembelajaran kooperatif adalah pembelajaran dimana terdapat system belajar dan bekerja dalam kelompok-kelompok kecil berjumlah 4-5 orang secara kolaboratif sehingga dapat merangsang peserta didik lebih bergairah dalam belajar. Dari pengertian tersebut dapat disimpulkan bahwa pembelajaran kooperatif adalah cara belajar dalam kelompok-kelompok kecil yang saling bekerjasama dan diarahkan oleh guru untuk mencapai tujuan yang diharapkan, (Dedy, 2013) 
Fasilitas yang diberikan oleh guru untuk melibatkan peran peserta didik dan pembelajaran kooperatif memiliki beberapa nilai positif bagi mereka, misalnya dengan diskusi kelompok: pembelajaran akan lebih menarik, dapat mengaktifkan peserta didik, membuat mereka lebih antusias dan bersemangat dalam belajar. Metode pembelajaran tersebut memberikan kesempatan kepada peserta didik untuk dapat belajar dari sesamanya.

Pembelajaran dari teman sebaya memberikan banyak keuntungan bagi peserta didik yaitu lebih mudah memahami dan mengerti penjelasan yang disampaikan temannya, bisa saling berbagi dengan sesama teman dengan cara Tanya jawab dan memberikan umpan balik terhadap jawaban yang diberikan. Keaktifan peserta didik membuat suasana diskusi kelompok menjadi hidup yang menandakan mereka memegang peran utama dalam kegiatan pembelajaran. Aktivitas ini pun berdampak pada prestasi belajar yang mereka raih. Jika dilibatkan dalam kegiatan pembelajaran peserta didik akan mendapatkan pengalaman langsung tentang materi yang dipelajari sehingga mereka dapat belajar lebih banyak dibandingkan mereka hanya mendengarkan secara pasif. Dengan demikian prestasi belajar mereka meningkat seiring dengan peningkatan aktivitas. Kondisi ideal inilah yang diharapkan dalam kegiatan pembelajaran

Sayangnya kondisi ideal tersebut belum selalu terjadi seperti yang dialami oleh penulis dalam kegiatan pembelajaran di kelas VIII.8 SMP Negeri I Praya Tahun Pelajaran 2019-2020. Peserta didik di kelas tersebut berjumlah 32 orang yang terdiri atas 16 putri dan 16 putra. Latar belakang prestasi belajar mereka di sekolah dasar beragam, ada yang tinggi, sedang, dan rendah. Hal itu berdampak pada prestasi belajar yang mereka raih di sekolah. Hasil ulangan harian dan ulangan tengah semester yang telah mereka ikuti juga menunjukkan hasil yang beragam. Ada beberapa peserta didik yang menunjukkan hasil yang menonjol, bahkan mencapai nilai yang sempurna. Namun ironisnya sekitar 50\% peserta didik belum mencapai ketuntasan.
Dalam hal aktifitas selama kegiatan pembelajaran, keberagaman juga masih nampak. Ada beberapa peserta didik yang sangat antusias dan aktif dalam bertanya atau menjawab pertanyaan. Namun banyak juga yang pasif, hanya berdiam diri tidak mau bertanya atau menjawab pertanyaan, melamun bahkan ada juga yang mengantuk dan berbicara dengan temannya sehingga kurang memperhatikan pelajaran.

Jika diadakan diskusi kelompok, belum semua peserta didik berperan aktif sesuai yang diharapkan. Memang sudah ada sebagian kecil yang sudah berdiskusi dengan baik namun masih ada juga peserta didik yang asyik bercerita dengan temannya, bukan membahas materi yang seharusnya mereka diskusikan. Sebagian kelompok hanya berdiam diri saja, tidak mau ikut andil memberikan masukan, pada akhirnya mereka hanya bergantung dengan anggota kelompok yang lebih aktif. Kondisi ini tentunya tidak ideal untuk aktifitas peserta didik dalam pembelajaran kooperatif.

Dari sisi guru, seharusnya guru berperan sebagai fasilitator bagi peserta didik untuk dapat aktif dalam kegiatan pembelajaran. Namun guru masih mendominasi jalannya pembelajaran dengan menyampaikan materi secara langsung melalui ceramah. Hal inipun berdampak pula pada kurang maksimalnya prestasi belajar yang diraih peserta didik.

Kesenjangan antara kondisi pembelajaran yang ideal dengan yang terjadi di kelas VIII.8 tersebut ingin diatasi oleh penulis dengan menerapkan pembelajaran kooperatif yang dapat mengembangkan berbagai kemampuan peserta didik yaitu dengan model window shopping (kunjungan gallery). Galery adalah pameran, yaitu kegiatan untuk memperkenalkan produk, karya atau gagasan kepada khalayak ramai. Karya peserta didik yang mungkin ditampilkan dalam pembelajaran IPA adalah berupa poster maupun model tentang suatu tema yang telah ditentukan. Sedangkan walk artinya berjalan, melangkah (Marini, 2013). Sehingga gallery walk dapat diartikan berjalan menuju ruang pameran (galeri). 
Untuk seterusnya model pembelajaran ini disebut kunjungan galeri (window shopping).

Tujuan metode pembelajaran window shopping (kunjungan galeri) menurut Asmani (2013), yaitu agar masing-masing anggota kelompok mendapat kesempatan untuk memberikan kontribusi mereka dan mendengarkan pandangan serta pemikiran anggota lainnya. Keuntungan metode dari metode ini bagi peserta didik antara lain: (1) kegiatan diskusi dapat meningkatkan kemampuan berpendapat, menghargai pendapat teman, berfikir kritis, dan memecahkan masalah secara berkelompok; (2) kegiatan pembuatan karya (poster) dapat meningkatkan kreatifitas dalam berkarya; (3) kegiatan pemaparan isi karya (poster) dapat meningkatkan kemampuan untuk memaparkan isi karyanya dan menjawab pertanyaan dari teman yang lain sebagai pengunjung galeri; (4) Kegiatan kunjungan galeri dapat meningkatkan kemampuan dalam mengamati dan bertanya tentang isi karya (poster) serta membuat resume karya-karya kelompok lain yang telah dikunjungi; (5) kegiatan imbas informasi dapat menyampaikan informasi hasil kunjungan galeri kepada teman yang lain; (6) Kegiatan post tes dapat mengetahui sejauh mana pemahaman materi dalam rangkaian kegiatan kunjungan galeri.

Melihat keunggulan model kunjungan galeri tersebut, penulis menemukan solusi yang tepat untuk mengatasi kesenjangan yang terjadi di kelas VIII.8, baik dari sisi peserta didik maupun guru. Sehingga penulis melakukan suatu penelitian tindakan kelas dengan judul “

Peningkatan Prestasi Belajar Peserta Didik Melalui Pendekatan Saintifik Model Pembelajaran Window Shopping (Kunjungan Galeri) Pada Materi Sistem Pencernaan Manusia Kelas VIII.8 SMP Negeri I Praya Tahun Pelajaran 2019 - 2020.

\section{Ruang Lingkup Penelitian}

Ruang lingkup penelitian ini yaitu:

$$
\text { Mengetahui apakah model }
$$

pembelajaran window shopping (kunjungan galeri) pada materi sistem pencernaan manusia dapat meningkatkan prestasi belajar peserta didik kelas VIII.8 SMP Negeri I Praya Tahun Pelajaran 2019-2020.

\section{Tujuan Penelitian}

Penelitian

ini bertujuan:

Meningkatkan prestasi belajar peserta didik melalui model pembelajaran window shopping (kunjungan galeri) pada materi sistem pncernaan manusia kelas VIII.8 SMP Negeri I Praya Tahun Pelajaran 2019-2020.

\section{KAJIAN PUSTAKA \\ Pendekatan Saintifik}

Pendekatan saintifik (scientific apporoach) menurut kemendikbud (2014) adalah model pembelajaran yang menggunakan kaidah-kaidah keilmuan yang memuat serangkaian aktivitas pengumpulan data melalui observasi , menanya, eksperimen, mengolah informasi atau data, kemudian mengkomunikasikan. Pendekatan saintifik telah dipergunakan dalam pendidikan di Amerika akhir abad ke-19 dimana pada saat itu pembelajaran sains menekankan pada metode laboratorium formalistik yang kemudian diarahkan pada fakta-fakta ilmiah. Pendekatan saintifik sebenarnya sudah digunakan dalam kurikulum di Indonesia dengan istilah learning by doing yang dikenal dengan cara belajar siswa aktif dalam melaksanakan kegiatan pembelajaran yang secara formal diadopsi dalam kurikulum 1975.

Tujuan pendekatan saintifik dalam pembelajaran antara lain untuk meningkatkan kemampuan berpikir peserta didik, membentuk kemampuan dalam menyelesaikan masalah secara sistematik, menciptakan kondisi pembelajaran supaya peserta didik merasa bahwa belajar merupakan suatu kebutuhan, melatih peserta didik dalam mengemukakan ide-ide, meningkatkan hasil belajar peserta didik, dan mengembangkan karakter peserta didik.

$$
\text { Proses pembelajaran dengan }
$$
menggunakan pendekatan saintifik diarahkan agar peserta didik mampu merumuskan masalah (dengan banyak menanya) bukan hanya menyelesaikan masalah dengan menjawab saja. Proses pembelajaran diharapkan diarahkan untuk melatih berpikir analitis (rutin dengan hanya mendengarkan dan menghapal semata (Majid, 2014). 


\section{Pembelajaran Kooperatif}

Metode pembelajaran adalah cara yang digunakan oleh guru dalam melaksanakan kegiatan belajar mengajar di kelas sebagai upaya untuk mencapai tujuan pembelajaran yang telah ditetapkan. Menurut Wina Sanjaya (2008:147), metode adalah cara yang digunakan untuk mengimplementasikan rencana yang sudah disusun dalam kegiatan nyata agar tujuan yang telah disusun tercapai secara optimal.

Metode pembelajaran kooperatif menurut Jacobsen (2009) dalah sekumpulan strategi pengajaran yang dirancang untuk mendidik kerjasama kelompok dan interaksi antar peserta didik. Tujuan metode ini yaitu hasil belajar akademik, penerimaan terhadap keragaman dan pengembangan terhadap keterampilan sosial.

Keuntungan metode pembelajaran kooperatif antara lain: mengajarkan kepada peserta didik menjadi percaya pada guru, kemampuan untuk berfikir, mencari informasi dari sumber lain dan belajar dari peserta didik lain, mendorong peserta didik untuk mengungkapkan idenya secara verbal dan membandingkan dengan ide temannya, dan membantu peserta didik belajar menghormati peserta didik yang pintar dan peserta didik yang lemah juga menerima perbedaan ini (Yamin, 2008).

\section{Model Window Shopping (Kunjungan Galeri)}

Ketika menyebut kata Window Shopping kita akan langsung membayangkan sebagai aktivitas jalan-jalan di pasar atau mall hanya sekedar melihat-lihat saja tanpa membeli apapun barang di mall tersbut. Sama halnya juga dengan model kooperatif window shopping ini dimana peserta didik melakukan kegiatan berjalan-jalan untuk mengamati hasil pekerjaan kelompok lain di dalam kelas. Namun pada posisi jalan-jalan ini bukan berarti peserta didik tidak mendapatkan apaapa akan tetapi mereka akan mendapatkan banyak sekali pengetahuan dari hasil kunjungan mereka ke tiap-tiap kelompok yang ada. Jadi secara umum dapat didefinisikan jika model pembelajaran window shopping ini merupakan model pembelajaran yang melibatkan peserta didik untuk berjalan-jalan mengamati hasl pekerjaan dari kelompok lain yang disajikan di dinding kelas, kemudian peserta didik tersebut mencatat hasil pekerjaan kelompok tersebut sebagai hasil dari kunjungan mereka. Kemudian saling mendiskusikan/berbagi dengan anggota kelompok mereka masingmasing. Dengan demikian setiap anggota yang berperan sebagai pengunjung juga akan berbelanja ilmu sebagai oleh-oleh bagi anggotanya yang sedang bertugas sebagai penjaga toko mereka dari kunjungan kelompok lain (Asnawi, 2019).

Menurut Machmudah dalam Muslihin (2013), Window shopping (kunjungan galeri) merupakan suatu cara untuk menilai dan mengingat apa yang telah peserta didik pelajari. Kunjungan galeri adalah suatu model pembelajaran yang mampu meningkatkan daya emosional peserta didik untuk menemukan pengetahuan baru dan dapat merangsang daya ingat jika sesuatu yang ditemukan itu dilihat secara langsung. Penggalerian hasil kerja dilakukan pada saat peserta didik telah mengerjakan tugasnya. Setelah semua kelompok mengerjakan tugasnya, guru memberikan kesimpulan dan klarifikasi sekiranya ada yang perlu diluruskan dari pemahaman peserta didik. Dengan demikian mereka dapat belajar dengan lebih menyenangkan sehingga tujuan pembelajaran yang diharapkan bias tercapai.

Tujuan pembelajaran dengan model window shopping (kunjungan galeri) antara lain: (1) menarik peserta didik ke dalam topik yang akan dipelajari; (2) memberi kesempatan kepada peserta didik untuk menunjukkan pengetahuan dan keyakinan mereka tentang topic yang akan di bahas (pemahaman yang benar maupun yang keliru); (3) Mengajak peserta didik menemukan hal yang lebih dalam dari pengetahuan yang sudah mereka peroleh; (4) Memungkinkan peserta didik mengembangkan pengetahuan dan keterampilan (seperti berfikir, meneliti, berkomunikasi, dan bekerjasama) dalam mengumpulkan informasi baru; (5) Memberikan kesempatan kepada peserta didik untuk memilah, mengolah dan menyajikan informasi dan pemahaman baru yang 
diperoleh; dan (6) member i kesempatan kepada peserta didik untuk menentukan sendiri cara mendemonstrasikan hal yang telah dipelajari (pemahaman, keterampilan, sikap dan nilai).

Langkah-langkah model pembelajaran window shopping (kunjungan galeri : (1) peserta didik dibagi ke dalam beberapa kelompok yang beranggotakan 4-5 orang; (2) Setiap kelompok diberikan kertas karton; (3) Menentukan topik atau tema pelajaran; (4) tiap kelompok mendiskusikan apa yang didapatkan oleh para anggotanya dari pelajaran yang mereka ikuti; (5) tiap kelompok membuat sebuah daftar pada kertas yang telah diberikan yang berisi hasil pembelajaran; (6) tiap kelompok menempel hasil kerjanya di dinding; (7) perwakilan kelompok berputar mengamati hasil kerja kelompok lain; (8) salah satu wakil kelompok menjelaskan setiap apa yang ditanyakan oleh kelompok lain. Dalam hal ini diperlukan pembagian tugas dalan kelompok yaitu ada anggota yang menjaga karya mereka untuk menjelaskan isinya kepada pengunjung dan ada pula anggota yang berkeliling untuk menggali informasi pada galeri kelompok lainnya.

Kelebihan model pembelajaran window shopping (kunjungan galeri) diantaranya adalah: (1) peserta didik terbiasa membangun budaya kerjasama memecahkan masalah dalam belajar; (2) terjadi sinergi saling menguatkan pemahaman terhadap tujuan pembelajaran; (3) membiasakan peserta didik bersikap menghargai dan mengapresiasi hasil belajar kawannya; (4) mengaktifkan fisik dan mental peserta didik selama proses belajar dan (5) membiasakan peserta didik memberi dan menerima kritik.

Berdasarkan uraian tersebut, window shopping (kunjungan galeri) merupakan suatu model pembelajaran yang mampu mengakibatkan daya emosional peserta didik untuk menemukan pengetahuan baru dan dapat mempermudah daya ingat jika sesuatu yang ditemukan itu dilihat secara langsung. Kunjungan galeri juga dapat memotivasi keaktifan dan kreatifitas peserta didik dalam proses belajar, sebab bila sesuatu yang baru ditemukan berbeda antara yang satu dengan yang lainnya maka dapat saling mempresentasikan atau mengkoreksi antara peserta didik, baik kelompok maupun antar peserta didik itu sendiri (Zaini, 2007).

\section{Prestasi Belajar Peserta Didik}

Setiap peserta didik pasti mengharapkan untuk meraih prestasi belajar setinggi mungkin di sekolah masing-masing. Menurut Djamarah (1994), prestasi adalah penilaian pendidikan tentang perkembangan dan kemajuan murid yang berkenaan dengan penguasaan bahan pelajaran yang disajikan kepada mereka dan nilai-nilai yang terdapat di dalam kurikulum. Sedangkan belajar merupakan perubahan tingkah laku untuk mencapai tujuan dari tidak tahu menjadi tahu atau suatu proses yang menyebabkan terjadinya perubahan tingkah laku dan kecakapan seseorang.

Sedangkan Sardiman dalam Djamarah (1994) menyatakan bahwa belajar adalah rangkaian kegiatan jiwa raga yang menuju perkembangan pribadi manusia seutuhnya, yang menyangkut unsur cipta, rasa, dan karsa serta ranah kognitif, afektif, dan psikomotorik. Jadi belajar merupakan suatu aktivitas yang sadar akan tujuan, yaitu terjadinya suatu perubahan dalam diri individu kearah yang lebih baik. Untuk meraih prestasi belajar ternyata peserta didik tidak bisa lepas dari banyak faktor yang mempengaruhi mereka. Menurut sujana (1989) faktor yang dapat mendukung prestasi belajar peserta didik adalah hasil belajar yang dicapai peserta didik yang dipengaruhi oleh du faktor utama yaitu faktor dari dalam diri peserta didik itu sendiri dan faktor yang dating dari luar diri peserta didik itu sendiri atau faktor lingkungan.

Dari uraian di atas dapat disimpulkan bahwa prestasi belajar adalah hasil belajar yang dicapai oleh peserta didik setelah mengikuti serangkaian proses pembelajaran. Hasil belajar tersebut dapat digambarkan secara kualitatif maupun kuantitatif.

\section{Pembelajaran IPA}

Pembelajaran IPA (Ilmu Pengetahuan Alam) atau sains merupakan suatu kegiatan untuk mempelajari fenomena atau gejala yang terjadi di alam semesta. Fenomena tersebut ditingkat SMP dapat dikelompokkan menurut 
sifatnya menjadi cabang ilmu fisika, kimia dan biologi. Tujuan pembelajaran IPA adalah supaya peserta didik dapat mengerti, memahami dan menerapkan konsep IPA serta mengantisipasi fenomena IPA yang ditemukan dalam kehidupan sehari-hari.

Sebagai ilmu yang mempelajari tentang alam, pembelajaran IPA tak dapat lepas dari kegiatan praktikum yang melibatkan peran langsung peserta didik, baik di dalam maupun di luar laboratorium. Sebagai rangkaian dari kegiatan praktikum, peserta didik juga harus memiliki kemampuan untuk menyampaikan ataupun memaparkan hasil kerja kepada sesama teman. Tujuannya yaitu supaya mereka terlatih untuk dapat menyampaikan buah pikirannya kepada sesama teman dan agar teman yang lain juga memperoleh ilmu dan pemahaman yang sama dengan yang mereka peroleh.

Salah satu metode yang dapat dilakukan untuk menyampaikan hasil kerja peserta didik kepada sesamanya dalam pembelajaran IPA yaitu dengan window shopping (kunjungan galeri), yang memiliki nilai positif yaitu semua peserta didik dapat belajar untuk saling memaparkan buah pikiran mereka sehingga seluruhnya mendapatkan pengetahuan yang sama tentang materi yang dipelajari.

Materi atau topik yang dipilih dalam penelitian ini adalah tentang Sistem Pencernaan Manusia. Topik tersebut dipilih karena dapat memberikan kesempatan dan ruang yang luas bagi peserta didik untuk mengetahui dan menuangkan ide yang terkait dengan komposisi zat pada bahan makanan yang di beli atau dimakan .

\section{Sistem Pencernaan Pada Manusia}

Tubuh kita membutuhkan energi untuk setiap kegiatan seperti belajar, berjalan ke sekolah, dan membaca buku. Tubuh juga menggunakan energy untuk mempertahankan suhu nomal sekitar $37^{\circ} \mathrm{C}$. Energi ini berasal dari makanan yang kamu makan. Sejumlah energy yang dibutuhkan untuk mendukung aktivitas metabolisme tubuhmu selama sehari berbeda-beda bagi setiap orang. Beberapa faktor yang mempengaruhi kebutuhan energy seseorang diantaranya adalah usia, jenis kelamin, serta aktivitas yang dilakukan. Keseimbangan energy dapat terjadi ketika kalori yang masuk dalam tubuh melalui makanan sama dengan kalori yang dikeluarkan melalui metabolism tubuh dan aktivitas otot. Jika kalori yang masuk dalam tubuh melebihi kalori yang dikeluarkan maka akan terjadi keseimbangan eergi positif (Zubaidah, 2017).

Makanan yang kita konsumsi seharihari harus mengandung enam jenis nutrisi yaitu karbohidrat, lemak, protein, vitamin, mineral, dan air. Karbohidrat, lemak dan protein dibutuhkan dalam jumlah yang banyak sedangkan vitamin dan mineral dibutuhkan dalam jumlah sedikit. Karbohidrat, lemak, protein, dan mineral merupakan nutrisi organik yang mengandung karbon. Sebaliknya, nutrisi anorganik seperti air dan mineral tidak mengandung karbon. Makanan yang mengandung karbohidrat, lemak, dan protein perlu dicerna atau dipecah terlebih dahulu oleh tubuh. Sedangkan air, vitamin, dan mineral dapat diserap langsung oleh sel-sel tubuh. Makanan yang mengandung karbohidrat merupakan sumber energi utama bagi tubuh. Satu gram karbohidrat menghasilkan 4,1 kalori. Terdapat tiga jenis karbohidrat yaitu gula, pati, dan serat. Gula disebut sebagai karbohidrat sederhana. Contoh makanan yang mengandung gula adalah buah-buahan, madu dan susu. Dua jenis karbohidrat lainnya yaitu pati dan serat disebut karbohidrat kompleks. Pati ditemukan dalam umbi-umbian seperti kentang dan makanan yang terbuat dari bijibijian. Serat sepert selulosa ditemukan di dinding sel tumbuhan. Makanan seperti roti gandum atau sereal, kacang-kacangan, sayuran dan buah-buahan merupakan sumber serat yang baik. Lemak atau lipid diperlukan tubuh karena menyediakan energy sebesar 9,3 kalori/gram, melarutkan vitamin A, D, E, K, dan menyediakan asam lemak esensial bagi tubuh manusia. Selama proses pencernaan lemak dipecah menjadi molekul yang lebih kecil yaitu asam lemak dan gliserol. Berdasarkan strukturnya, dikenal lemak jenuh dan lemak tak jenuh. Lemak jenuh biasanya padat pada suhu kamar, ditemukan dalam daging, susu, keju, minyak kelapa, dan minyak kelapa sawit. Lemak jenuh. Minyak nabati serta lemak yang ditemukan pada biji 
adalah lemak tak jenuh. Protein dibutuhkan sebagi penghasil energy, untuk pertumbuhan dan mengganti sel-sel tubuh yang rusak, pembuat enzim dan hormone, dan pembentuk antibody (sistem kekebalan tubuh). Protein yang kita makan dapat berasal dari hewan (protein hewani) dan dari tumbuhan (protein nabati). Bahan makanan yang mengandung protein hewani antara lain daging, ikan, telur, susu, dan keju. Bahan makanan yang mengandung protein nabati adalah kedelai, kacang hijau, dan kacang-kacangan lainnya. Selain karbohidrat, lemak, dan protein tubuh kita juga membutuhkan vitamin, mineral, dan air. Vitamin walaupun dibutuhkan dalam jumlah sedikit namun harus ada, karena vitamin diperlukan untuk mengatur fungsi tubuh dan mencegah beberapa penyakit. Vitamin dikelompokkan menjadi dua, yaitu vitamin yang larut dalam air (vitamin $B$ dan C) dan vitamin yang larut dalam lemak (A, D, E, dan K). Khusus vitamin D dapat terbentuk ketika kulit terkena sinar matahari, karena di dalam tubuh pro vitamin D. Tubuh memerlukan sekitar 14 jenis mineral, diantaranya kalium, fosfor, kalium, natrium, besi, iodium, dan seng. Air sangat penting bagi tubuh kita tubuh. Tubuh dapat kehilangan air ketika bernapas, berkeringat, berkeringat, buang air besar maupun buang air kecil. Kehilangan air tersebut harus segera diganti dengan minum air sebanyak 2 liter atau 8 gelas sehari (Yuliati, 2017).

\section{HASIL DAN PEMBAHASAN}

\section{HASIL PENELITIAN}

Penelitian tindakan kelas ini dilaksanakan dalam dua siklus. Tiap siklus terdiri atas empat tahap yaitu: perencanaan, tindakan, pengamatan dan refleksi.

Siklus I berlangsung selama 5 jam pelajaran (3 $\mathrm{X} \quad 40$ menit) atau 1 kali pertemuan, diawali dengan diskusi tentang topik yang telah ditentukan, kemudian kegiatan dilanjutkan dengan pembuatan poster (karya). Setelah jadi, poster (karya) dipajang pada dinding dan siap dikunjungi pada kegiatan window shopping (kunjungan galeri).

Siklus II dilaksanakan dalam 2 kali pertemuan dengan alokasi waktu 5 jam pelajaran (5 X 40 menit). Secara keseluruhan pelaksanaan Siklus II berlangsung lebih lancar dan kondusif jika dibandingkan dengan siklus I karena peserta didik telah belajar dari pengalaman pada siklus I. Prestasi belajar peserta didik dinilai dari hasil post test sebagai evaluasi secara tertulis setelah mengikuti kegiatan. Penilaian tambahan diberikan terhadap karya yang dihasilkan peserta didik secara berkelompok, yaitu meliputi nilai proyek dari karya yang dipajang dan nilai portofolio dari laporan hasil kunjungan galeri

\section{Hasil post tes siklus I}

Dari hasil Analisis data prestasi peserta didik dalam mengerjakan soal post test selama siklus I dan siklus II yang meliputi empat macam kriteria nilai, yaitu tidak tuntas (TT, nilai < 72), tuntas dan cukup (TC, nilai 72-82), tuntas dan memuaskan (TM, nilai 83-90) serta tuntas dan sangat memuaskan TSM, nilai 91-100).

\section{PEMBAHASAN HASIL}

Prestasi Peserta Didik dalam Mengerjakan Soal Postest (grafik) Setelah pelaksanaan kunjungan galeri pada tiap siklus dilakukan post test untuk mengetahui sejauh mana penguasaan materi peserta didik. Berdasarkan table di atas, pada hasil post test siklus I terlihat adanya 9 peserta didik atau sekitar 28\% yang belum mencapai ketuntasan (TT). Dimungkinkan karena mereka kurang sungguh-sungguh dalam mengikuti kegiatan ini, banyak bercanda dengan teman, atau pasif saja sehingga tidak bisa menguasai materi. Namun demikian sebagian besar sisanya telah berhasil mencapai ketuntasan dengan criteria yang bervariasi, yaitu 12 peserta didik tuntas dan cukup (TC), 8 peserta didik tuntas dan memuaskan (TM), serta 3 peserta didik tuntas dan sangat memuaskan (TSM). Ini berarti mereka telah dapat menyerap ilmu dari teman sebaya dan berhasil menguasai materi dengan baik.

Pada siklus II terjadi penurunan jumlah peserta didik yang tidak tuntas (TT), yaitu hanya 4 orang atau sekitar $12 \%$. Sebagian besar sisanya telah mencapai ketuntasan dengan criteria yang bervariasi yaitu 10 orang tuntas dan cukup (TC), 10 orang tuntas dan memuaskan (TM), serta 8 orang tuntas dan sangat memuaskan (TSM). Ini menunjukkan 
adanya peningkatan jumlah peserta didik yang berhasil mencapai ketuntasan. Mereka lebih maksimal dalam menyerap informasi dan menguasai materi dalam pelaksanaan Siklus II karena telah belajar dari pengalaman pada siklus I.

Jika dibandingkan, prosentase ketuntasan pada Siklus I sebesar 69\% sedangkan pada siklus II sebesar $87 \%$, atau terjadi kenaikan sebesar $18 \%$. Berdasarkan kriteria penilaian prestasi belajar, maka ketuntasan belajar peserta didik dalam siklus II telah melebihi kriteria keberhasilan, yaitu lebih dari $85 \%$ peserta didik telah berhasil mencapai ketuntasan. Sehingga dapat disimpulkan bahwa model kunjungan galeri terbukti dapat meningkatkan prestasi belajar peserta didik.

\section{Nilai Karya Peserta Didik secara Berkelompok}

Hasil penilaian tambahan dalam kegiatan ini berupa nilai poster (karya) peserta didik secara berkelompok terdiri atas nilai proyek yaitu poster yang dipajang, dan nilai portofolio yaitu laporan hasil kunjungan galeri seperti yang tercantum pada table 1 .

Nilai rata-rata poster dari kedelapan kelompok pada siklus I sebesar 78 dan pada siklus II 84 atau mengalami peningkatan sebesar $7 \%$. Meskipun hanya sedikit, namun secara rata-rata kenaikan ini patut diapresiasi karena terjadi secara menyeluruh. Poster yang dipajang sudah memenuhi seluruh kriteria penilaian yaitu desain dan kesesuaian isi dengan materi pembelajaran. Tiap kelompok memiliki kreativitas yang bervariasi dalam membuat poster.

Sedangkan nilai rata-rata laporan hasil window shopping (kunjungan galeri) kedelapan kelompok menunjukkan peningkatan yang cukup besar dari pelaksanaan siklus I ke siklus II. Pada siklus I diperoleh nilai rata-rata sebesar 79 dan pada siklus II di peroleh nilai rata-rata sebesar 87 atau mengalami peningkatan sebesar $8 \%$. Angka tersebut cukup menggembirakan karena menunjukkan prestasi tiap kelompok dalam membuat laporan hasil kunjungan galeri. Mereka memperlihatkan kesungguhan dan keseriusan dalam pembuatan laporan ini tidak hanya sekedar menyelesaikan tugas.
Berdasarkan hasil pembahasan penelitian tindakan kelas tersebut, bahwa model pembelajaran window shopping (kunjungan galeri) dapat meningkatkan prestasi belajar IPA peserta didik. Kegiatan ini terbukti dapat mewujudkan kondisi pembelajaran ideal bagi peserta didik seperti yang diharapkan oleh penulis.

\section{SIMPULAN}

Hasil penenilitian tindakan kelas ini dapat disimpulkan sebagai berikut :

Model pembelajaran window shopping (kunjungan galeri) dapat meningkatkan prestasi belajar peserta didik kelas VIII.8 SMP Negeri I Praya Tahun 2019-2020 dalam pembelajaran IPA (Sistem Pencernaan Manusia ) sebesar $18 \%$.

Rekomendasi

Sehubungan dengan hasil penelitian ini maka direkombinasikan kepada:

1. Peserta didik; yaitu supaya dapat meningkatkan aktivitas belajar untuk mencapai tujuan pembelajaran dan prestasi belajar yang maksimal

2. Guru; yaitu hasil penelitian ini diharapkan dapat meningkatkan kompetensi dan profesiaonalisme guru dalam merancang dan melaksanakan kegiatan pembelajaran yang aktif, kreatif, inovatif dan menyenangkan demi mencapai tujuan pembelajaran serta meningkatkan prestasi belajar peserta didik

3. Sekolah; yaitu dapat menambah referensi dan khazanah bagi kepustakaan sekolah, yang suatu saat mungkin berguna sebagai bahan pertimbangan dalam menetapkan kebijakan kurikulum sekolah.

\section{DAFTAR PUSTAKA}

Asnawi, 2019. Model Pembelajaran Kooperatif Tipe Window Shopping

Dedi, Pengertian Pembelajaran Kooperatif (Cooperatif Learning) menurut para ahli, pengertian pembelajaran kooperatif.html. 21 Oktober 2013

Djamarah, Saeful Bahri. 1994. Prestasi Belajar dan Kompetensi Guru 
Dedi, Pengertian Pembelajaran Kooperatif (Cooperative Learning) Menurut Para

Ahli,http://dedi26.blogspot.com/2 013/05/pengertianpembelajarankooperatif. html. 21 Oktober 2013.

Djamarah, Syaiful Bahri. 1994. Prestasi Belajar dan Kompetensi Guru. Surabaya:

Usaha Nasional. Gunter, Mary A; Estes, Thomas H. Mintz, Susan L. 2007. Instruction: A Model Approach. Pearson Education, Inc.

Hisyam Zaini, 2007. Strategi Pembelajaran Aktif, Yogyakarta: Center For Teaching Staff Development.

Asnawi, 2019. Model Pembelajaran Kooperatif Tipe Window Shopping

Jacobsen, David A.; Eggen, Paul; Kauchak, Donald. 2009. Metode-metode

Pengajaran. Jakarta: Penerbit Pustaka Pelajar. Marini, Efektifitas Penggunaan Metode "Gallery Walk" dalam Meningkatkan Kemampuan Siswa pada Pembelajaran Bahasa Arab di Madrasah Tsanawiyah AlFatah Tarakan. www.unhas.ac.id/arab/data_fl/JU RNAL_Marini.docx, tgl. 22 Mei 2013.

Mushlihin Al-Hafizh, Metode Gallery Walk dalam Pembelajaran, http://www.referensimakalah.com /2013/01/metode-gall ery-walkdalam-pembelajaran.html, $22 \mathrm{Mei}$ 2013

Nana Sudjana, 1989. Cara Belajar Siswa Aktif dalam Proses Belajar Mengajar. Bandung: Sinar Baru

Nasution, SM. A. 2000. Berbagai Pendekatan dalam Proses Belajar dan Mengajar. Jakarta: Bumi Aksara Nurkencana. 2005. Evaluasi Hasil Belajar Mengajar. Surabaya: Usaha Nasional.

Riadi, Muchlisin. 2019. Pengertian, Prinsip dan Langkah Pendekatan Saintifik
Singgih D. Gunarsah, 1985. Psikologi Perkembangan Anak dan Remaja. Jakarta: Gunung Mulia.

Wijaya. Wina. 2008. Pembelajaran dalam Implementasi Kurikulum Berbasis Kompetensi, Jakarta: Kencana.

Yamin, Martinis; Ansari, Bansu. 2008. Taktik Mengem bangkan Kemampuan Individual Siswa. Jakarta: Gaung Persada Press.

Yuliati lia, 2017. Ilmu Pengetahuan Alam. Kementrian Pendidikan dan Kebudayaan Republik Indonesia, Jakarta. 